lowing sharp protests from Congress and elsewhere, however, this option has been discarded, and it looks as if funding for the magnetic fusion programme, although not as high as some would like to see, will be maintained at a reasonable level, although with a slight shift in emphasis from the tokamak projects to those involving mirror confinement.

At the same time the department is looking closely at other, less conventional schemes. Currently about 12 of these are being funded by the department-out of the 100 or so proposals which are received each year-at an annual cost of about $\$ 15$ million.

These various schemes are now being evaluated both from the scientific and the technological points of view, with the intention of selecting the two or three most promising to receive significant additional funding.

\section{More or fewer problems?}

At present, these various alternatives are so far behind the more main-line schemes that some are sceptical whether they can, in fact, ever catch up sufficiently to compete realistically. Others, however, feel that such additional funding could provide a breakthrough to a new system presenting fewer problems than those now being considered.

"We want to broaden the programme and develop alternatives to tokamak. I don't think anybody can say which approach will work the best, Dr Deutch said last week. "It's a matter of keeping the door open to new ideas," said another department official.

One result of holding back from putting all the research eggs into one basket-the lessons of which the administration has learnt from its experiences with the Clinch River Fast breeder-is that it could lengthen the timescale for the commercialisation of fusion energy. Dr Deutch is now predicting that the first commercial fusion reactor will be in operation by 2005 , and the second ten years after that.

In Europe, energy officials have been taking careful note of the two US reports. But. if it were necessary. it would not be an easy matter to shift the EEC five-year research programmes, which run from 1975-80. Mirror machines, of which there were many a decade ago in Europe, have been abandoned, and the commitment to JET is substantial.

The commissioner responsible for JET. M. Reginald Saison. said this week that "we are reassessing the technological problems". But he could not say if research funds would be shifted towards engineering and away from pure confinement research. "The matter is under discussion".

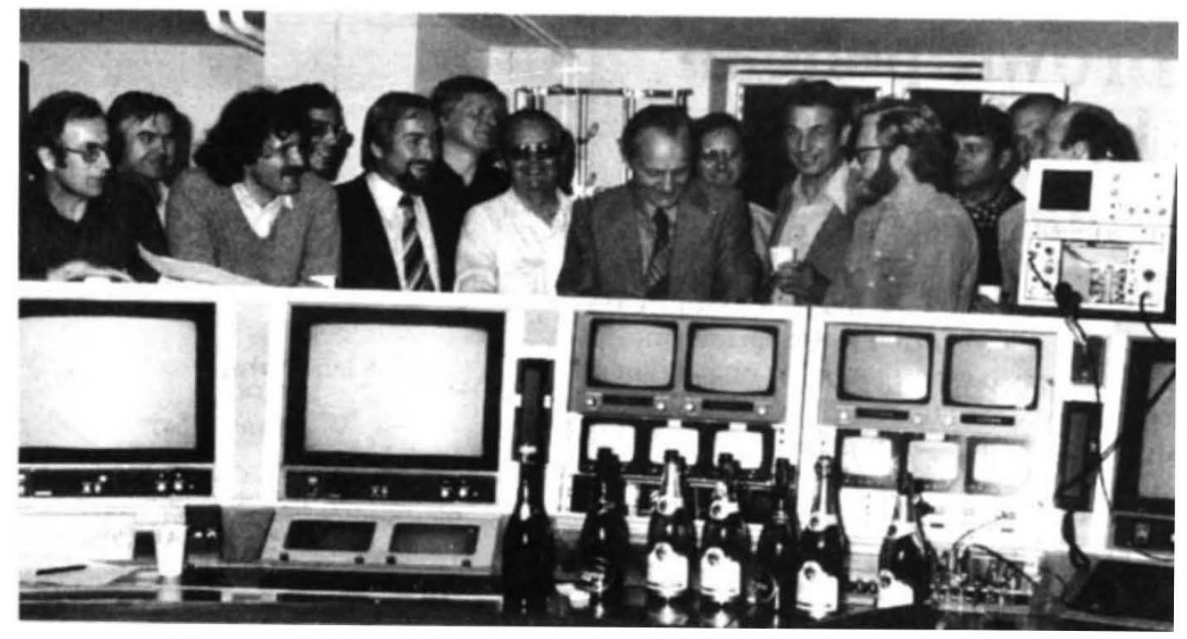

PETRA'S FIRST LIGHT: the first synchrotron light from PETRA, Germany's brand new accelerator, causes the physicists to celebrate. Centre, Professor Gustav-Adolf Voss, leader of the project. PETRA has already stored a 3 milliamp, $5 \mathrm{GeV}$ electron beam for 2 hours, and accelerated the beam from 5 to $8 \mathrm{GeV}$. This week it should accept positrons in the opposite direction and produce its first collisions. Commissioning is going "extremely well" says Voss, with the machine behaving almost exactly as predicted.

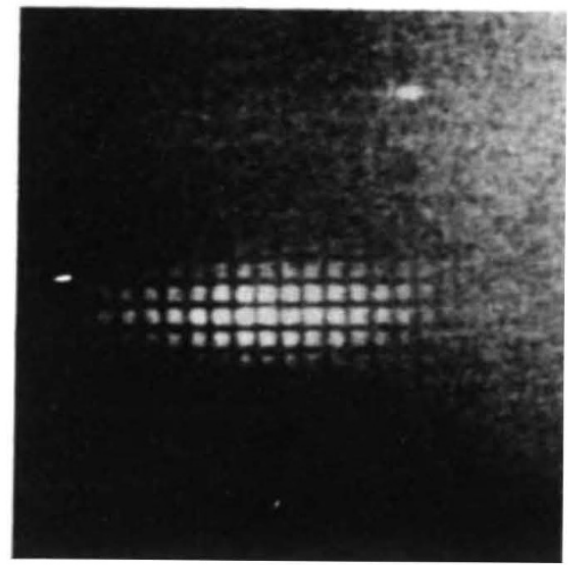

\title{
NIH relaxes recombinant DNA guidelines
}

A revised version of the guidelines for conducting research involving recombinant DNA techniques, in which the safety precautions required for a range of experiments would be substantially reduced, was due to be published this week by the US Department of Health, Education and Welfare.

The guidelines have been prepared by Dr Donald Fredrickson, director of the National Institutes of Health, following extensive discussion in both the scientific and the lay community, and taking into account the knowledge that has been gained about the use of the techniques since the existing guidelines were first published in June 1976

In the light of this new knowledge, the revised guidelines are expected both to relax the safety requirements for certain types of experiments, and exempt others from the need for regulation.

It is also expected that the new draft will compromise on an earlier suggestion that local biohazard committees be set up with the power to give the go-ahead to recombinant DNA experiments performed within the guidelines, merely supplying $\mathrm{NIH}$ with formal notification.

Following concern that such a system could lead to variations in interpretation of the guidelines, it is now expected that NIH approval will, as at present, still be required before new projects can go ahead, but that the local committees will be able to renew approval for such projects.

The draft version of the revised guidelines will be open for public discussion for a period of 60 days, after which a final version will be prepared and promulgated by $\mathrm{Dr}$ Fredrickson. $\mathrm{Mr}$ Joseph Califano, secretary of HEW, says in a preamble to the guidelines that he is particularly keen to receive comments on their nontechnical aspects, and a public hearing is to take place towards the end of the comment period, i.e. in mid-September.

Meanwhile in the House of Representatives. a bill sponsored by Representatives Harley Staggers and Paul Rogers to extend the NIH guidelines to cover all experiments involving recombinant DNA in both the public and private sector, of which little has been heard since March, is now expected to be debated on the floor of the House within the next few weeks.

But in the possible absence of any legislation, NIH is contemplating offering both a registration and a hostvector certification service to private companies as the basis of a system of voluntary compliance.

David Dickson 